\title{
Allelopathic effects of sandbur leachate on switchgrass germination: observations
}

\author{
RODER, W., S.S. WALLER, AND J.L. STUBBENDIECK
}

\section{Abstract}

Switchgrass (Paricum virgatum L.) extablishment from seed was limited by current-year's growth of sandbur [Cenchrus longispinus (Hack.) Fern.] in the Nebraske Sandhils. Stand reduction was greater than other warm-season grasses seeded at the same time, indicating posdble allelopathy. Germination studies were conducted to evaluate potential sandbur allelopathy with switchgrass. Fresh sandbur plant material was extracted with distilled water for 24 hours. Root, shoot, and whole plant leachate $(2 \% \mathrm{w} / \mathrm{v})$ from sandbur plants collected between the vesetative and culm elongation stage and whole plant leachate $(2,4 \% \mathrm{w} / \mathrm{v})$ from vezetative or mature plants was used. Switchgrass germination was not influenced by root, shoot, or whole plant leachate from sandbur plants composited over phenological stages. However, leachate reduced the length of the primary root and increased shoot length measured at 11 days. Generally, the response was greater with vegetative sandbur compared to mature and with the higher leachate concentration. Whole plant leachate $(4 \% \mathrm{w} / \mathrm{v})$ from vezetative sandbur reduced switch rrass germination compared to mature plant leachate. The relatively rapid development of a sandbur cover prior to switchgrass seed germination on sandy sites may affect switchgrass germination and early root development through an allelopathic interaction. Since tillage promotes rapid sandbur development, no-till seedinga should be considered for switchgrass on sandy soik.

Key Words: allelopathy, Cenchrus longispinus (Hack.) Fern., Panicum virgatum L. germination, root, shoot

Weed competition was one of the major reasons for poor establishment of warm-season grasses from seed (Martin et al. 1982, Vallentine 1971). Aldrich (1984) restricted the definition of competition to competition for some factor limited in supply. Water was, in most situations, the first limiting factor in grass seedings and weed competition resulted in moisture stress (Bryan and McMurphy 1968, Dudley and Holt 1963). In the Nebraska Sandhills, sandbur [Cenchrus longispinus (Hack.) Fern.] was a problem weed with dryland seedings of warm-season grasses (Kocher 1986, Oldfather 1984, Roder 1985). Switchgrass (Panicum virgatum L.) establishment was limited in the presence of sandbur, while other seeded warm-season grasses had better establishment (Oldfather 1984). The exceptionally poor switchgrass establishment compared to that of other warm-season grasses seeded in the same experiment suggested the possibility of sandbur allelopathy. Rice (1984) reported that several pioneer species in tall grass old-field successions produced allelochemicals toxic to themselves as well as other species.

Most plants have the potential to produce allelopathic chemicals that inhibit other plants (Lovett 1982). Allelopathic effects have been reported for many grasses (Bhowmik and Doll 1982, Bokhari 1978, Chambers and Holm 1965, Peters and Zam 1981, Rice 1980). However, sandbur was not identified as a weed with potential allelopathic activity in agroecosystems (Duke 1985).

Allelopathy is a particularly difficult phenomenon to study (Aldrich 1984). Duke (1985) established a set of criteria to provide undisputable proof of allelopathy. However, Aldrich (1984) stated

\footnotetext{
Authors are rescarch assistant and professors, Department of Agronomy, University of Nebraska-Lincoln, Lincoln 68583. Published as Paper No. 8063, Jour. Ser. Nebraska Agr. Exp. Sta.

This study was conducted with support from the U.S. Department of Agriculture. Manuscript accepted 29 June 1987.
}

that the concern for allelopathy was not so much the proof as it was the influence on weed-crop relationships. The purpose of this study was to quantitate the first criterion of Duke (1985): to demonstrate the existence of interference between sandbur plants and switchgrass germination. The effect of sandbur leachate from different plant parts and phenological stages was evaluated.

\section{Materials and Methods}

Sandbur plants were collected in July and August 1984 from 'abandoned' irrigated crop land with sandy soil (mixed, mesic Aquic Ustipsamment) in central Nebraska. Plants were excavated with the roots, washed, and parts used as specified. Fresh, turgid plant material was soaked in distilled water at $25^{\circ} \mathrm{C}$ for $24 \mathrm{hr}$ and filtered through glass wool. A pilot study indicated leachate effects on the root length of germinating switchgrass for concentrations of $1 \%$ (g sandbur material used per $100 \mathrm{ml}$ water). For the experiments reported, concentrations of 2 and $/$ or $4 \%$ were used. These are relatively low rates when compared to similar germination studies (Peters and Zam 1981, Bhowmik and Doll 1982).

The switchgrass 'Nebraska 28' was used for the experiments. Experimental units were petri dishes lined with 2 filter papers (No. 3 Whatman) on which 20 seeds were placed. Leachate or water (control treatment) in the amount of $7 \mathrm{ml}$ was added to each dish. To prevent fungus development in the petri dishes, $0.1 \%$ captan \{N-\{(trichloro-methyl)thio\}-4-cyclohexene-1,2-dicarboximide\} was added to all solutions used. Experiments were conducted in a germinator with alternating temperatures of $35^{\circ} \mathrm{C}$ for $8 \mathrm{hr}$ (light period) to $25^{\circ} \mathrm{C}$ for 16 hours (dark period). Shoot length, primary root length, and number of seeds germinated were recorded after 11 days. Germination was considered to occur when both radicle and shoot were $1 \mathrm{~mm}$ or longer.

Two trials were conducted to evaluate the importance of plant part and plant age in sandbur allelopathy:

Trial 1: Sandbur plants between the vegetative and culm elongation stage were used to prepare leachates from roots, shoots, or whole plants at a rate of $2 \%(w / v)$.

Trial 2: Leachates were prepared using entire young sandbur plants (vegetative stage) and older plants (culm elongation stage) at rates of 2 and $4 \%(w / v)$.

A completely randomized design with 4 and 6 replicates for the first and second experiment, respectively, was used. Treatments were compared using orthogonal comparisons.

\section{Results and Discussion}

Trial 1: Switchgrass germination was not reduced by sandbur shoot, root, or whole plant leachate $(2 \% \mathrm{w} / \mathrm{v})$. Sandbur leachate decreased primary root elongation $(P<0.01)$ while increasing shoot length $(P=0.02)$ of switchgrass compared to a water control (Table 1). This effect was independent of plant part.

Trial 2: Switchgrass germination was inhibited by vegetative sandbur leachate, particularly at the $4 \%$ ( $w / v)$ rate (Table 2 ), while leachate from elongated sandbur plants did not reduce switchgrass germination at either rate. Whole plant leachate from vegetative and elongated sandbur reduced switchgrass primary root elongation. In both cases the higher leachate rate was more inhibitory. When used at the rate of $4 \%(w / v)$ leachate from both phenological stages increased shoot length of switchgrass. 
Table 1: Iffects of sandbur leachate from different plant parts used at concentrntion of $2 \%(\mathrm{w} / \mathrm{v})$, on primary root length $(\mathrm{mm})$, shoot lenth (mm), and germination $(\%)$ of switchgrass. Treatments were compared using orthogonal contrasts.

\begin{tabular}{lccc}
\hline \hline Treatment & $\begin{array}{c}\text { Primary root } \\
\text { length (mm) }\end{array}$ & $\begin{array}{c}\text { Shoot } \\
\text { length (mm) }\end{array}$ & $\begin{array}{c}\text { Germination } \\
(\%)\end{array}$ \\
\hline Control & 22.3 & 13.8 & 67.5 \\
Whole plant & 15.1 & 17.5 & 70.0 \\
Plant part & & & \\
$\quad$ Shoot & 12.0 & 17.8 & 62.5 \\
$\quad$ Root & 13.4 & 15.9 & 69.0 \\
Contrasts & & PR $>\mathrm{F}$ & \\
Control vs others & $<.01$ & 0.02 & 0.93 \\
Shoot vs root & 0.31 & 0.21 & 0.31 \\
Whole plant vs shoot and root & 0.06 & 0.61 & 0.41 \\
\hline
\end{tabular}

Table 2. Efiect of andbur phenolopical stage (veretative and culm elongation) and leachate concentration $(0,2,4 \%, w / v)$ on primary root lenth $(\mathrm{mm})$, shoot length $(\mathrm{mm})$, and germination $(\%)$ of switchgrass. Treatments were compared uing orthozonal contrasts.

\begin{tabular}{|c|c|c|c|c|}
\hline Treatment & $\begin{array}{c}\text { Leachate } \\
(\%, w / v) \\
\text { conc. }\end{array}$ & $\begin{array}{l}\text { Primary } \\
\text { root length } \\
\text { (mm) }\end{array}$ & $\begin{array}{l}\text { Shoot } \\
\text { length } \\
(\mathrm{mm})\end{array}$ & $\begin{array}{l}\text { Germina- } \\
\text { tion } \\
(\%)\end{array}$ \\
\hline $\begin{array}{l}\text { Control } \\
\text { Phenological stage } \\
\text { of sandbur }\end{array}$ & 0 & 21.4 & 13.1 & 72.5 \\
\hline $\begin{array}{l}\text { Vegetative } \\
\text { Vegetative } \\
\text { Culm elongation } \\
\text { Culm elongation }\end{array}$ & $\begin{array}{l}2 \\
4 \\
2 \\
4\end{array}$ & $\begin{array}{l}17.8 \\
11.7 \\
19.9 \\
13.8\end{array}$ & $\begin{array}{l}13.9 \\
15.4 \\
12.2 \\
14.5\end{array}$ & $\begin{array}{l}70.8 \\
59.2 \\
72.5 \\
74.2\end{array}$ \\
\hline Contrasts & & & $-P R>F$ & \\
\hline $\begin{array}{l}\text { Control vs others } \\
\text { Vegetative vs culm } \\
\text { elongation } \\
2 \% \text { vs } 4 \% \text { in vegetative } \\
2 \% \text { vs } 4 \% \text { in culm } \\
\text { elongation }\end{array}$ & & $\begin{array}{l}0.15 \\
<.01\end{array}$ & $\begin{array}{l}0.08 \\
0.16\end{array}$ & $\begin{array}{r}0.28 \\
<.01 \\
<.01\end{array}$ \\
\hline
\end{tabular}

The apparent allelopathy associated with young sandbur plants is consistent with weed ecology. Inhibition of potential competitors during the early establishment phase would minimize competition, resulting in a sandbur monoculture. Field observations indicated sandbur was a very prevalent early colonizer on sandy soils.
As sandbur plants matured the allelopathic effect would decrease allowing other plants to invade. Sandbur provides a very rapid cover on abandoned sandy soils and is beneficial to the successional process as a pioneer plant. However, its mechanism of establishment may be detrimental to the establishment from seed of plants of higher successional stages.

Results of both trials suggested that sandbur leachate restricted primary root elongation of switchgrass. Inhibited and/or delayed primary root elongation in seeded switchgrass could be detrimental to its establishment when competition is severe and moisture or nutrients are limited. Assuming that the further criteria for allelopathy are validated in subsequent research, the use of pre-emergent herbicides would be required for sandbur control as opposed to cultural methods and/or post-emergent herbicides in establishing warm-season grasses from seed. Seeding directly into residue would be preferable to a clean tillage, which often stimulates sandbur germination.

\section{Literature Cited}

Aldrich, R.J. 1924. Weed-crop ecology, principle in weed management. Breton Pub. North Scituate, Mass.

Bhowmlk, P.C., and J.D. Doll. 1982. Corn and soybean response to allelopathic effects of weed and crop residues. Agron. J. 74:601-606.

Bokhari, U.G. 1978. Allelopathy among prairie grasses and its possible ecological significance. Ann. Bot. 42:127-136.

Bryan, G.G., and W.E. MeMurphy. 1968. Competition and fertilization as influences on grass seedlings. J. Range Manage. 21:98-101.

Chambers, E.E., and L.G. Holm. 1965. Phosphorus uptake as influenced by associated plants. Weeds 13:312-314.

Dudley, D.I., and E.C. Holt. 1963. Establishment of warm-season grasses on the Grand Prairie. Texas Agr. Exp. Sta. Misc. Pub. 672.

Duke, S.O. 1985. (ed.) Weed physiology Vol. I, Reproduction and ecophysiology. CRC Press, Inc. Boca Raton, Fla.

Kocher, E., and J.L. Stubbendieck. 1986. Broed casting grass seed to revegetate sandy soils. J. Range Manage. 39:555-557.

Lovett, J.V. 1982. The effects of allelochemicals on crop growth and development, P. 93-1 10. In. J.S. McLaren (ed.), Chemical manipulation of crop growth and development. Butterworths, London.

Martin, A.R., R.S. Moomar, and K.P. Vogel. 1982. Warm-season grass establishment with atrazine. Agron. J. 74:916-920.

Oldfather, S.S. 1984. Reseeding abandoned cropland in the Nebraska Sandhills. M.S. Thesis, Univ. Nebraska, Lincoln.

Peters, E.J., and A.H.B.M. Zam. 1981. Allelopathic effects of tall fescue genotypes. Agron. J. 73:56-58.

Rice, E.L. 1980. Some roles of allelopathy in pasture and forage crops. Proc. 37th Southern Pasture and Forage Crop Improvement Conf.

Rice, E.L. 1984. Allelopathy 2nd ed. Academic Press, Inc. New York.

Roger, W. 1985. Factors influencing grass seeding success on a sandy soil. M.S. Thesis, Univ. Nebraska, Lincoln.

Vallentine, J.F. 1971. Range development and improvements. Brigham Young Univ. Press. Provo, Utah. 